\title{
Risk assessment in municipal wastewater treatment plant
}

\author{
Magdalena Łój-Pilch ${ }^{1, *}$, Anita Zakrzewska ${ }^{1}$, and Ewa Zielewicz ${ }^{1}$ \\ ${ }^{1}$ Institute of Water and Wastewater Engineering, Silesian University of Technology, Gliwice, Poland
}

\begin{abstract}
Each technical facility is exposed to a risk that will hinder or prevent its proper functioning. Risk assessment is a component of the risk management process in municipal wastewater treatment plants, the purpose of which is to reduce the occurrence of events as well as their resulting effects, which adversely affect the operation of the treatment plant. The authors, having based their work on the identification of risk-related phenomena, estimated the value of risk and determined its acceptability. The result of the work was to obtain a risk matrix in other words, a risk map with a designated hierarchy. This could then be used as a basis to determine the level of risk that an event triggered. This allows for faster response to risky situations and an optimal selection of remedies.
\end{abstract}

\section{Introduction}

The concept of risk is inseparably related to any system or technical device. Complicated technical facilities, such as municipal wastewater treatment plants, are particularly susceptible to risk. They consist of many connected devices working with variable loads of pollutants, hydraulic load as well as changing and difficult weather conditions, especially in winter. During the operation of such specific facilities, there are a number of hazards that may lead to emergency events and losses, therefore it seems necessary to implement a continuously verified risk management process at sewage treatment plants [1-3].

Risk management consists in undertaking of activities that aim to make an assessment, control the risk and monitor the actions taken. The first stage of risk assessment the identification of risk - leads to the determination of risk factors and the determination of the type of risk and factors that cause it $[4,5]$. In the case of sewage treatment plants, at an earlier stage of research, the following types of risk were identified: qualitative, operational, ecological and, related to each of them, financial risk. The factors that cause them were determined as: internal, external, latent, explicit, ordinary and extraordinary [6-8]. The subject of this article is the presentation of subsequent stages of risk assessment - estimation and determination of its acceptability. Risk management has been well

\footnotetext{
* Corresponding author: magdalena.loj-pilch@.polsl.p1
} 
researched and described in the literature in the field of water supply systems, for e.g. in [9-12]. In the case of municipal sewage treatment plants, have been made attempts of modelling risk, e.g. [13], and few studies on its management also can be found $[14,15]$. On this basis, the authors of the paper attempt to analyze and assess the risk of municipal sewage treatment plants based on real operational data.

\section{Risk assessment}

Risk management in an enterprise should lead to a situation in which the management of the facility will be aware of the presence of a risk during the operation of the plant and its size, while its level in the current operation of the plant does not exceed the contractually accepted risk limit [4, 5]. Risk assessment is an element of this process [6-8]. The result of risk assessment of a technical facility should be a risk hierarchy, which is best represented graphically, creating the so-called risk map. An illustrative picture of the risk hierarchy is determined on the basis of an estimation of the risk value and the determination of its acceptability [16].

\subsection{Risk identification}

The main purpose of risk identification is to get acquainted with the functioning of the facility, to determine the risk factors and the types of risks that cause them. Risk recognition can be divided into the following stages [6-8]:

- becoming acquainted with the characteristics of the tested facility,

- conversation with the manager and employees of the facility,

- analysis of historical data regarding events that occurred on the site,

- verification of the results obtained.

The risk-related situations identified in this way should be subjected to further stages of risk assessment.

\subsection{Risk estimation}

Risk estimation consists in the adoption of its measures and on the basis of the determination of the risk value. The choice of measure depends primarily on the availability of input data, their number and reliability, selected for estimating risk parameters and expected output values. Therefore, you can distinguish $[14,15,17,18]$ :

- quantitative numbers - determine the exact numerical value of risk, e.g. probability,

- qualitative variables - they determine the risk value as a relative quantity

- on a conventionally agreed scale, different for each case,

- $\quad$ single numbers - they focus on only one parameter,

- comprehensive resolutions - they consider several parameters, most often the probability and amount of losses,

- focused numbers - the result obtained is a single numerical value,

- $\quad$ spread numbers - the result obtained is a function of the distribution of a random variable, usually presented in graphic form.

Figure 1 presents an example of a risk matrix of a so-called risk map resulting from an undertaken estimation. 


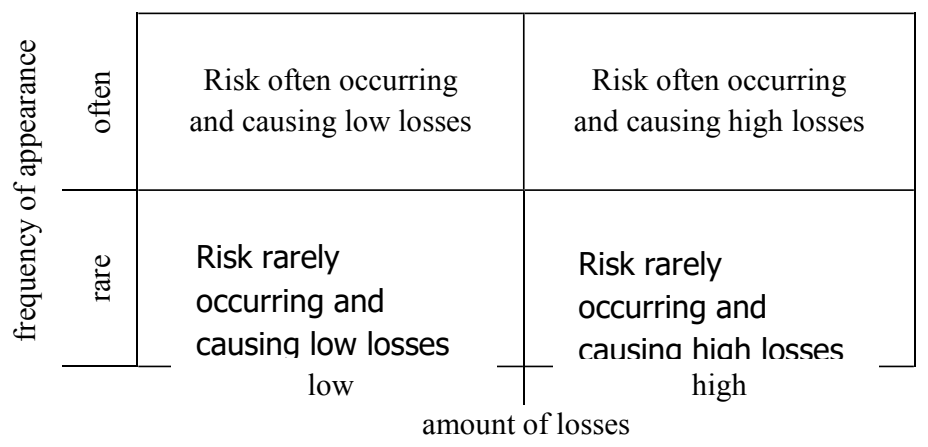

Fig. 1. Risk map [9].

\subsection{Risk admissibility}

The admissibility of risk is determined on the basis of existing legal acts and standards. In the case of municipal wastewater treatment plants, the basic document is the Regulation of the Minister of Environment from November 18, 2014 [19]. In reference to an individual facility, it could also be considered to issue a permit for specific water treatment. The mentioned act defines the conditions of sewage disposal - the highest acceptable values of selected indicators or the minimum percentage of contamination reduction and the maximum number of samples that do not meet these requirements. These are immission criteria, the fulfilment of which ensures that discharged sewage will not cause contamination of the receiver $[14,15]$.

The following risk tolerance levels are distinguished $[14,15,18]$ :

- low risk (acceptable) - is perceived as not relevant to the overall functioning of the facility, does not require special security measures,

- medium (tolerated) risk - conditionally acceptable risk, when the costs of risk reduction are disproportionately large to the possibility of reducing losses,

- high risk (unacceptable) - is directly related to the occurrence of threats to the environment, health and human life, requires immediate action and reduction of risk regardless of the cost.

The risk acceptability should be applied to the previously obtained risk map (Fig. 1). In this way, graphical interpretations of the enterprise risk hierarchy are obtained (Fig. 2).

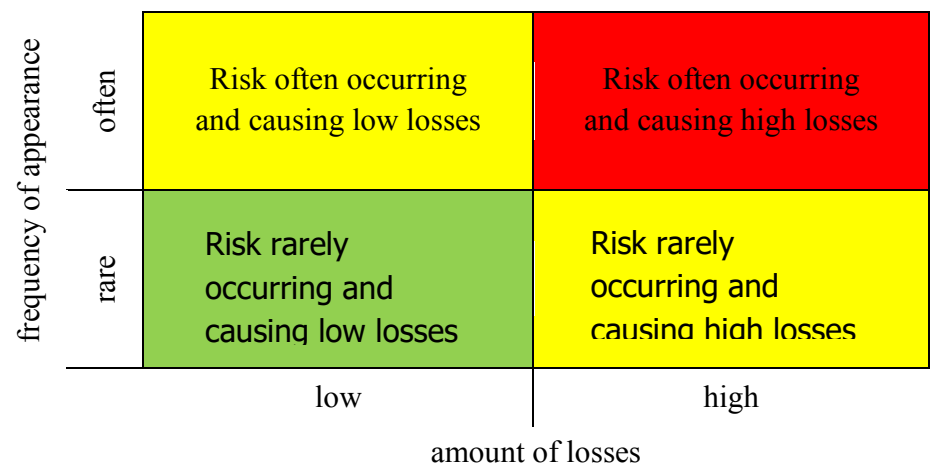

Fig. 2. Risk hierarchy. 


\section{Obtained results}

The functioning of a municipal sewage treatment plant using activated sludge technology located in the Upper Silesian Industrial District (GOP) was considered. The sewage plant serves 42 thousand inhabitants, which in addition to municipal sewage also receives industrial sewage from meat processing and electroplating. The risks assessed were identified at an earlier stage of research work. A three-year operational period of the treatment plant was analyzed, during which 36 different risk-related situations occurred with varying frequency [6]. Estimating the risk of municipal sewage treatment plants consisted in determining the incidence rate (I) of an adverse event and determining the amount of losses (L) resulting from its consequences. As the basic risk parameters, the authors accepted the values of F and L. Events, depending on the incidence, were grouped as rare, common and very common, and weighed from 1 to 3 (Table 1.)

Table 1. Incidence rate (I).

\begin{tabular}{|c|c|c|}
\hline \multirow{2}{*}{ Occurring events } & \multicolumn{2}{|c|}{ Incidence rate } \\
\cline { 2 - 3 } & {$[\mathbf{1} /$ year $]$} & (I) \\
\hline rare & $\leq 2$ & 1 \\
\hline common & $2-4$ & 2 \\
\hline very common & $\geq 4$ & 3 \\
\hline
\end{tabular}

The amount of losses (L) was determined on the basis of the type of risk assigned to each event and numerical weights were also assigned to them (Table 2). Table 3 presents examples of events together with the incidence rate (I) and assigned loss (L). On the basis of the determined values I and L, a risk map was prepared taking into account its hierarchisation (Fig. 3).

All analyzed events were in the area of acceptable and tolerated risk, with the advantage of the former, which proves the proper functioning of the treatment plant. In order to better illustrate the risk occurring in the normal operation of the sewage treatment plant, a risk map was prepared taking into account events occurring at individual devices of the technological sewage treatment plant (Fig. 4).

Table 2. Amount of losses (L).

\begin{tabular}{|c|c|}
\hline Type of risk & Amount of losses (L) \\
\hline qualitative & 1 \\
\hline qualitative, operational & 2 \\
\hline qualitative, operational, financial & 3 \\
\hline qualitative, operational, ecological, financial & 4 \\
\hline
\end{tabular}


Table 3. Examples of events together with the incidence rate (I) and amount of losses (S).

\begin{tabular}{|c|c|c|c|c|c|}
\hline \multirow[b]{2}{*}{ Device } & \multirow[b]{2}{*}{ Event } & \multicolumn{2}{|c|}{ Incidence rate } & \multirow[b]{2}{*}{ Type of risk } & \multirow{2}{*}{$\begin{array}{c}\text { Amount } \\
\text { of losses } \\
\text { (L) }\end{array}$} \\
\hline & & [1/year] & (I) & & \\
\hline Bar screen & clogging of bars & 4.33 & 3 & qualitative & 1 \\
\hline Grit chamber & $\begin{array}{l}\text { large dump of } \\
\text { greasy sewage }\end{array}$ & 2.67 & 2 & qualitative & 1 \\
\hline $\begin{array}{l}\text { Activated } \\
\text { sludge } \\
\text { chamber }\end{array}$ & $\begin{array}{c}\text { emergence of } \\
\text { filamentous } \\
\text { bacteria }\end{array}$ & 0.33 & 1 & $\begin{array}{l}\text { qualitative, } \\
\text { operational }\end{array}$ & 2 \\
\hline
\end{tabular}

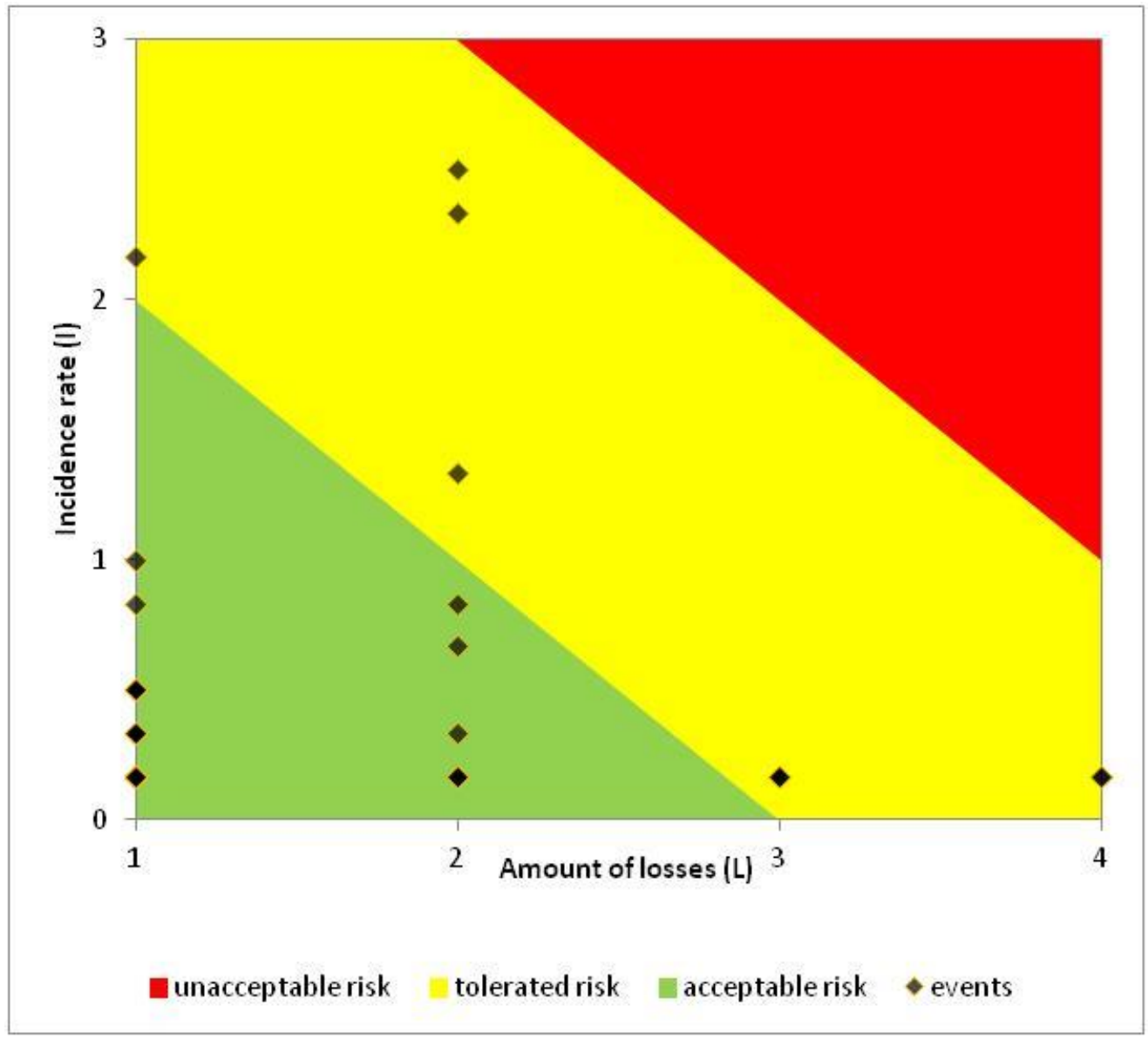

Fig. 3. A risk map taking into account its hierarchy. 


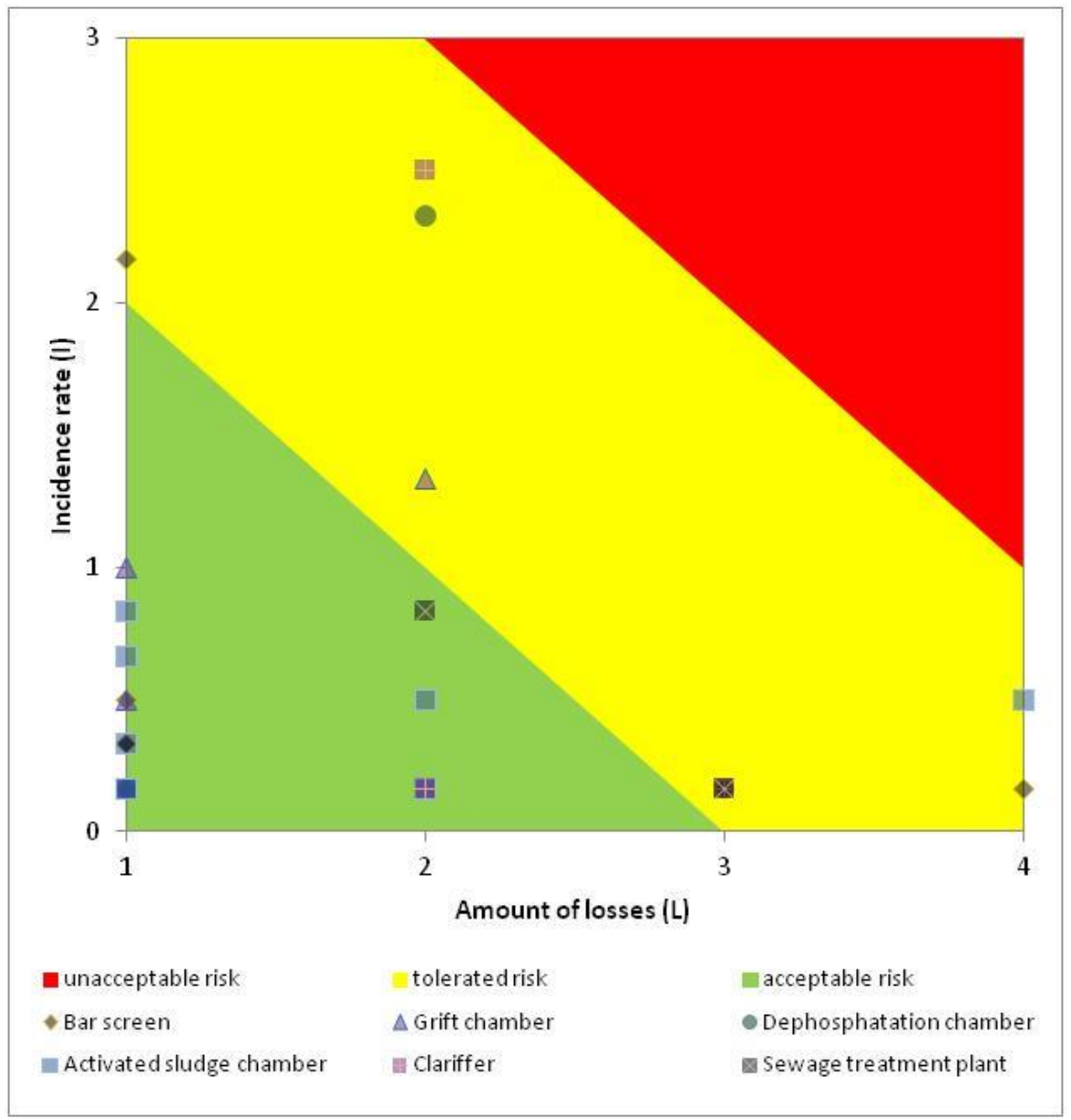

Fig. 4. A risk map taking into account its hierarchy with division into technological line devices

The highest risk level was assigned to events located in the activated sludge chamber, dephosphatation chamber, clarifier and on the bar screen. The first three of these devices are responsible for biological - chemical treatment. The last - the bar screen, is the first device in the technological process and is responsible for mechanical cleaning.

\section{Conclusions}

Analyzing the results of the risk map, it can be noted that the largest density of points representing events in the treatment plant is in the area of acceptable risk $(\mathrm{I}=<0,1>; \mathrm{L}=\{1\})$. The largest losses $(\mathrm{L}=4)$ were attributed to events that occurred at the bar screen and in the activated sludge chamber. These are the devices most exposed to risk occurrence. The bar screen is the first in the technological process to come into contact with sewage, so it is exposed to damage resulting from the physical properties of the sewage. The circulating activated sludge chamber is a device in which biological wastewater treatment takes place, so it is on the one hand exposed to the risk associated with the change in the composition of wastewater and on the other hand, its influence is affected by external conditions, such as ambient temperature. There were no events in the area of unacceptable risk. It provides information about proper functioning of the 
treatment plant, good training of the crew and conscious decision making by the management of the facility.

This work was supported by Research Funds For Young Researchers awarded to the Institute of Water and Wastewater Engineering of the Silesian University of Technology.

\section{References}

1. D. Andraka, L. Dzienis, Zeszyty Naukowe Politechniki Białostockiej. Inżynieria Środowiska 16, 24-28 (2003)

2. T. Żaba, A. Królikowski, J. Królikowska, Inżynieria Ekologiczna 24, 215-225 (2011)

3. E. Kulińska, Logistyka - nauka 2, 385-409 (2011)

4. J. Zawiła-Niedźwiecki, Zarządzanie ryzykiem operacyjnym $w$ zapewnianiu ciagłości działania organizacji (edu-Libri, 2013)

5. Y. Y. Haimes, Risk Modeling, Assessment, and Menagement (John Wiley \& Sons, 2009)

6. M. Łój-Pilch, A. Zakrzewska, E. Zielewicz, E3S Web of Conferences, 44 (2018)

7. M. Łój-Pilch, A. Zakrzewska, E. Zielewicz, Instal 4, 61-63 (2018)

8. M. Łój-Pilch, A. Zakrzewska, E. Zielewicz, Proceedings of Ecopole 12, 195-201 (2018)

9. J. Rak, Istota ryzyka $w$ funkcjonowaniu systemu zaopatrzenia $w$ wode (Oficyna Wydawnicza Politechniki Rzeszowskiej, 2004)

10. J. Rak, B. Tchórzewska-Cieślak, Czynniki ryzyka w eksploatacji systemów zaopatrzenia w wode (Oficyna Wydawnicza Politechniki Rzeszowskiej, 2007)

11. J. Rak, Bezpieczna woda wodociagowa. Zarzadzanie ryzykiem w systemie zaopatrzenia $w$ wodę (Oficyna Wydawnicza Politechniki Rzeszowskiej, 2009)

12. R. Iwanejko, Technical Transactions. Environment Engineering 102, 8, 113-127 (2005)

13. D. Andraka, L. Dzienis, Middle Pomeranian Scientific Society Of The Environment Protection 15, 1111-1125 (2013)

14. R. Iwanejko, S. M. Rybicki, Gaz, woda i technika sanitarna 2, 10-13 (2008)

15. R. Iwanejko, S. M. Rybicki, Gaz, woda i technika sanitarna 3, 34-38 (2008)

16. J. Zawarska, Zarządzanie i Finanse 1, 65-75 (2012)

17. R. Iwanejko, Czasopismo Techniczne. Środowisko Z8-S3, 113-127 (2006)

18. J. Rak, Monografia Komitetu Inżyierii Środowiska PAN, 28 (2005)

19. Rozporządzenie Ministra Środowiska z dnia 18 listopada 2014 r. w sprawie warunków, jakie należy spełnić przy wprowadzaniu ścieków do wód lub do ziemi, oraz w sprawie substancji szczególnie szkodliwych dla środowiska wodnego (Dz.U. 2014 poz. 1800) 